ISSN: 2146-3042

DOI: $10.25095 /$ mufad.625644

\title{
Türev Finansal Araçların Muhasebe Standartlarına Göre Muhasebeleştirilmesi*
}

Hakan AYGÖREN** Emin KURTCEBE ${ }^{* * *}$

\section{$\ddot{O Z Z E T}$}

Dünyadaki ekonomik sınırlar ortadan kalkması neticesinde mal, hizmet ve sermaye akımları ulusal boyuttan uluslararası boyuta taşınmıştır. Küreselleşme olarak adlandırılan bu durum ile dünya artık tek bir pazar haline gelmiştir. Bu gelişmeler, dünya finans piyasalarında da etkilerini göstermiş ve farklı ülkelerdeki finansal piyasalar birbiriyle bütünleşmiştir. Küreselleşmenin getirdiği zorlu rekabet şartlarındaki işletmelerin faaliyetlerini sürdürebilmesi ve maruz kalınan risklerin önlenebilmesi için geleneksel finansal araçlara alternatif olabilecek yeni finansal araçlar geliştirilmiştir. Bu finansal araçların en önemlisi ise, geleneksel finansal araçlardan türetilen ve risk yönetiminde etkin bir şekilde kullanılan türev finansal araçlardır. Finansal piyasalarda yoğun bir şekilde kullanılan türev finansal araçların, özüne uygun bir şekilde muhasebe kayıtlarına alınması gerekmektedir. Bu çalışmanın amacı; uluslararası finansal raporlama standartları kapsamında, türev finansal araç sözleşmelerinin muhasebeleştirilmesi ve gerçeğe uygun değer çerçevesinde riskin kayıt altına alınmasidır.

Anahtar Kelimeler: Türev Finansal Araçlar, Türev Araçların Muhasebeleştirilmesi, UFRS.

JEL Sınıflandırması: M41, G23.

\section{Accounting Of Derivative Financial Instruments In The Framework Of Accounting} Standards

\section{ABSTRACT}

As the economic borders around the world have been lifted, goods, services and capital flows have moved from the national dimension to the international dimension. With this situation called globalization, the world has become a single market. These developments were also influential in world financial markets and financial markets in different countries were integrated. New financial instruments have been developed that can be used as an alternative to traditional financial instruments in order to enable companies operating in tough competition by globalization to continue their operations and to avoid exposure to risks. The most important of these financial instruments are derivative financial instruments derived from traditional financial instruments and used effectively in risk management.Derivative financial instruments used intensively in financial markets must be taken to accounting records in accordance with the purpose. The aim of this work is, accounting of derivative financial instrument contracts and fair valuation of the risk within the framework of international financial reporting standards.

Keywords: Derivative Financial Instruments, Accounting of Derivative Instruments, IFRS

Jel Classification: M41, G23.

\footnotetext{
* Bu çalışma, Emin Kurtcebe'nin 2015 yılında Pamukkale Üniversitesi Sosyal Bilimler Enstitüsünde savunmuş olduğu "Türev Finansal Araçlar ve Muhasebeleştirilmesi” adlı doktora tezinden üretilmiştir.

** Prof. Dr., Pamukkale Üniversitesi, İktisadi İdari Bilimler Fakültesi, haygoren@pau.edu.tr, ORCiD ID: 00000001-5502-4040.

*** Dr., Denizli Serbest Muhasebeci Mali Müşavirler Odası, eminkurtcebe@gmail.com, ORCiD ID: 0000-00028147-0332.
} 


\section{GİRIŞ}

Yakın bir tarihte ortaya çıkmış olmalarına rağmen, gerçekte tarih boyunca türev araçların kullanımına rastlanılmaktadır. İlk türev sözleşmeler, M.Ö. 1750 yılında, Mezopotamya'da kil tabletlere yazılmıştır. Kayıtlardaki ilk vadeli işlem sözleşmeleri, Eski Yunan filozofu Thales'in kışın, bahardaki zeytin hasılatı için yağhanelerle yaptığı ve alım opsiyonlarına benzeyen anlaşmalardır. Forward sözleşmelerin yapıldığı ilk borsa, Londra' daki Kraliyet Borsası (Royal Exchange) olmuştur. İlk organize türev araç piyasası, 1848 yılında kurulan Chicago Ticaret Borsas1 (Chicago Board of Trade-CBOT), halen faaliyette olan, dünyanın en eski ve en büyük vadeli işlemler borsasıdır. Bilinen ilk resmi forward sözleşme, 13 Mart 1851 tarihli ve Haziran teslimli 10.5 ton dayanak varlığı içeren mısır sözleşmesidir.

Ekonomideki ve dolayısıyla piyasalardaki gelişmelere paralel olarak yatırımcıların karşı karşıya kaldıkları risklerin niteliği ve çeşitliliğinin artması sonucu risk yönetebilmek için yeni finansal araçlara ihtiyaç doğmuştur. 1971 yılında Bretton Woods Sisteminin çökmesi, mevcut finansal araçların günün ihtiyaçlarını karşılayamaması, dünyada çeşitli finansal krizlerin yaşanması, riski yok etmeyi amaçlayan farklı nitelikte finansal araçların oluşmasına neden olmuştur. Türetilen bu araçlara, Türev Finansal Araçlar denilmiştir.

Öncelikle gelişmiş ülkelerde tarım ürünleri üzerine işlem görmeye başlayan, daha sonra ise menkul kıymet, döviz ve finansal göstergeler üzerine düzenlenen türev finansal araç sözleşmeleri, yatırımcıların yoğun ilgisiyle karşılaşmış, bunun sonucunda da türev finansal piyasalar faaliyete geçmiştir. Türev finansal araçlar, öngörülemeyen ekonomik gelişmeler nedeniyle oluşan dövizdeki dalgalanmalara ve fiyat risklerine karşı yatırımcılara korunma imkanı sağlayarak finansal sistemin temel görevlerinden biri olan risk yönetimini daha kolay ve düşük maliyetli hale getirmektedir.

Türkiye'de, 1980 yılı öncesinde, ekonominin dışa kapalı ve devletçi bir yapıya sahip olması, para ve sermaye piyasalarının fazla gelişmemiş olması nedeniyle türev işlemler ile ilgili bir gelişme olmamıştır. 24 Ocak 1980 tarihinde alınan "24 Ocak Kararları", Türk ekonomisi ve piyasalarında önemli değişiklikler yaratmıştır. Söz konusu gelişmeler, faiz oranı ve döviz kuru gibi değişkenlerde dalgalanmaların yaşanmasına neden olmuştur. Ekonomik birimler, türev ürünlere ihtiyaç duymaya ve gelişim hızı çok yavaş da olsa tezgahüstü piyasalarda kullanmaya başlamışlardır. 28 Kasım 1995 tarihinden itibaren Merkez Bankası bünyesinde Piyasalar Genel Müdürlüğü, Döviz ve Efektif Piyasaları Müdürlüğü bünyesinde Vadeli (Forward) Döviz Alım-Satım Piyasası faaliyet göstermeye başlamıştır. Tarihsel süreç içerisinde Türkiye, İstanbul Altın Borsası bünyesinde açılan Vadeli İşlemler ve Opsiyon Piyasası (1997), İstanbul Menkul Kıymetler Borsası bünyesinde açılan Vadeli İşlemler Piyasası (2001) ve Vadeli Opsiyon Borsası (2005) olmak üzere üç farklı organize türev piyasaya sahip olmuştur. 5 Nisan 2013 tarihinde, ülkemizdeki mevcut borsalar; İMKB, VOB ve İstanbul Altın Borsası, yapılanmayla Borsa İstanbul (BİST) çatısı altında birleştirilmiştir.

Finansal piyasalarda yaygın olarak kullanılan türev finansal araçlar, bazı sorunları da beraberinde getirmiştir. $\mathrm{Bu}$ sorunların başında, türev araçların muhasebe kayıtlarına alınması gelmektedir. Bu finansal araçları kullanan işletmeler için bunların finansal tablolarda nasıl raporlanacağı, hangi değerleme ölçüsünün kullanılacağı, bu araçlardan doğan kar ve zararların finansal tablolara ne zaman ve nasıl aktarılacağı, son derece önemli konuları oluşturmaktadır. 


\section{TÜREV FINANSAL ARAÇLAR}

Türev finansal araçlar; belli miktardaki standart bir malın, menkul kıymetin, finansal göstergenin ya da yabancı paranın işlem anında belirlenmiş fiyattan, belirli bir yerde ve belirli bir tarihte satın alınmasını ya da satılmasını öngören alım satım anlaşmalarıdır.

Değeri başka bir finansal varlığın veya malın değerine doğrudan bağlı olan finansal araçlar türev finansal araç olarak adlandırılmaktadır. Türev finansal araçların değeri, mal ya da döviz, faiz, hisse senedi gibi bir finansal varlığın değerinden türetilmektedir. Dolayısıyla, türev finansal araçlar; bir faiz oranına, ürün fiyatına ya da döviz kuruna bağlı olarak değer oluşturan ve sahibine sözleşmesel hak ve yükümlülükler sağlayan finansal araçlardır.

Türev finansal araçlara dayalı yapılan sözleşmeler, alınıp satılabilir sözleşmelerdir. Alan açısından finansal varlık niteliğinde olup, yükümlülük altındaki işletmede ise finansal borç niteliğindedir.

Türev finansal araçlar, dayanak varlığın sahipliğinin el değiştirmesine gerek olmaksızın, bu varlıkla ilgili hak ve yükümlülüklerin ticaretine imkân sağlar.

Türev finansal araçlar, öncelikle mal piyasalarında, daha sonra ise yaygın olarak finansal piyasalarda kullanılmaya başlanmıştır. Gerek bireysel, gerekse kurumsal yatırımcılar türev finansal araçları genellikle; "Riskten Korunma (hedding)", "Spekülasyon" ve "Arbitraj" amaçları doğrultusunda kullanırlar.

\subsection{Forward Sözleşmeler}

Forward; "belirli bir miktar ve kalitedeki para, döviz, altın, mali araç ve diğer türev ürünlerin önceden belirlenen fiyatla, gelecekteki bir tarihte, organize olmayan bir piyasada alım ve satımını kapsayan, teslim amaçlı bir vadeli işlemdir.” (Örten, 2001；39).

Forward işlemlerinin temel özellikleri aşağıdaki şekilde sıralanmaktadır;

Forward, teslim amaçlı bir vadeli işlemdir. Bu nedenle, forward sözleşmeler, vadeli işlem sözleşmeleri olarak da ifade edilir.

Forward sözleşmeler, standart sözleşmeler değildir. Forward sözleşmelerinde genelde serbestlik hakimdir ve özel bir yasal düzenleme söz konusu değildir.

Forward sözleşmesine konu olan varlığın teslim yeri, teslim zamanı, miktarı, kalitesi gibi konularda standartlaşma aranmamaktadır.

Forward sözleşmeler, önceden belirlenen vade gününde tarafların edinimlerini, teslim ve ödemelerini yerine getirmeleri ile kapanır.

oluşur.

Forward sözleşmelerde kâr veya zarar vade sonunda, işlem gerçekleştiğinde 
Finansal piyasalardaki türev işlemler, üç grupta incelenmektedir.

Döviz Forward Sözleșmeleri: İki taraf arasında, belirli tutardaki bir yabancı paranın başka bir para birimine çevrilerek, bugünden belirlenmiş geleceğe ait bir tarihte teslimi konusunda yapılan sözleşmelerdir. (Chambers, 2007; 43)

Faiz Forward Sözleșmeleri: Faiz riskinden korunmak için yapılan bu vadeli sözleşmelerdir. Faiz forward sözleşmelerinde taraflar, belli tutardaki anaparaya, belirli bir süre için uygulanacak olan faiz oranı üzerinde anlaşırlar. Bu orana da forward faiz oranı denir.

Ticari Mal Forward Sözleșmeleri: Bu sözleşmeler, bir malı, gelecekteki bir tarihte, sözleşme tarihinde saptanan belirli bir fiyattan almaya ya da satmaya zorunlu k1lan sözleşmelerdir. Teslim tarihi, yeri, mal miktarı ve niteliği anlaşma yapıldığı sırada belirlenir.

\subsection{Futures Sözleşmeler}

Futures sözleşmeler, standart miktar ve kalitede bir varlığı önceden belirlenmiş bir fiyattan, gelecekte belirli bir tarihte teslim etme ya da teslim almaya ilişkin olarak düzenlenen yasal bir sözleşmedir. (T.C. Milli Eğitim Bakanlığı, 2007; 19)

Forward işlemlerde ortaya çıkabilen güven eksikliğini giderebilmek amacıyla geliştirilen futures piyasaları, gerçekte organize forward piyasalarıdır. Futures sözleşmeler, forward sözleşmeler ile aynı amacı ve özellikleri taşımaktadır. Aralarındaki temel farklılık, future sözleşmelerin standart olması ve organize borsalarda işlem görmesidir.

Alıcı ve satıcı arasında üçüncü bir kurum olarak futures borsası yer almaktadır. Piyasayı bu borsa düzenlemekte, tüm futures sözleşmeleri bu borsada alınıp satılmakta, alıcı ve satıcılar birbirini tanımamaktadır. Mal ya da menkul kıymet teslimi ve kalitesi ile ilgili tüm taahhütler borsanın garantisi altındadır.

\subsection{Opsiyonlar}

Opsiyon; satın alan tarafa, bir mal veya kıymeti, gelecekte belirli bir tarihte, belirli bir fiyattan, belirlenen miktarda alma veya satma hakkını sağlayan sözleşmedir.

Opsiyon sözleşmesi, alıcı taraf açısından bir hak sağlamakta, buna karşılık satıcı tarafı bu hakkı satan taraf olarak yükümlülük altına sokmaktadır. Alıcı taraf, opsiyon sözleşmesinde tanınan hakkı satın alırken satıcıya, "opsiyon primi" öder. Opsiyon sözleşmeleri, ödenen opsiyon primiyle sözleşme sahibine alım veya satımla ilgili opsiyon kullanma hakkı sağlar. Opsiyonları diğer türev ürünlerden ayıran en önemli fark, tanınan hakkın kullanılıp kullanılmamasıdır. Opsiyon işleme sokulmadığı takdirde zarar, ödenen primle sınırlı kalmaktadır. Dolayısıyla, sınırlı zarar olasılığı ve yüksek kaldıraç potansiyeli, vadeli işlem sözleşmelerinin bir ileriki aşaması olan opsiyonların üstünlükleri arasında sayılmaktadır.

Vadelerine göre opsiyon sözleşmeleri; Amerikan Opsiyonu ve Avrupa Opsiyonu olmak üzere ikiye ayrılır. Amerikan opsiyon sözleşmeleri, sözleşmede belirtilen vadeden önce işleme konulabilirler. Avrupa opsiyon sözleşmeleri, sadece sözleşmede belirtilen vade gününde işleme konulabilirler. 
Taraf olanlara sağlanan haklar açısından opsiyonlar, alım opsiyonu ve satım opsiyonu olmak üzere ikiye ayrılmaktadır.

a. Alım Opsiyonu (Call Option): Alım opsiyonu, opsiyonu alan tarafa belirli bir vadede veya vadeye kadar, önceden belirlenen fiyat üzerinden, belirli miktar ve nitelikteki dayanak varlığı alma hakkını veren, ancak almayı zorunlu tutmayan, satan tarafı ise alıcının talebi halinde satmaya yükümlü kılan sözleşmedir.

Bir yatırımcı gelecekte, ilgilendiği menkul kıymetin fiyatının yükseleceğini düşünüyorsa, bugünden ilgili menkul kıymetin fiyatını sabitlemek için alım opsiyonu satın alır. Vade geldiğinde alıcı taraf, spot piyasadaki menkul kıymetin fiyatı ile opsiyon sözleşmesindeki fiyatı karşılaştırarak opsiyonu kullanıp kullanmayacağına karar verir.

\begin{tabular}{|l|l|}
\hline \multicolumn{2}{|l|}{ ALIM OPSIYONU (Call Option) } \\
\hline Piyasa Fiyatı $>$ Kullanım Fiyatı + Prim & KARDA (In The Money) \\
\hline Piyasa Fiyatı $=$ Kullanım Fiyatı + Prim & BAŞABAŞ (At The Money) \\
\hline \multicolumn{1}{|c|}{ Piyasa Fiyatı $<$ Kullanım Fiyatı + Prim } & ZARARDA (Out Of The Money) \\
\hline
\end{tabular}

b. Satım Opsiyonu (Put Option): Satım opsiyonu, opsiyonu alan tarafa, belirli bir vadede veya vadeye kadar, önceden belirlenen fiyat üzerinden, belli miktar ve nitelikteki dayanak varlığı satma hakkını veren, ancak satmaya zorunlu tutmayan, satan tarafi ise opsiyon alıcısının talebi halinde satmaya yükümlü kılan sözleşmedir.

Satım opsiyonu alan tarafın ileride fiyatların düşeceği yönünde bir beklentisi vardır. Beklentisi doğru çıktığı takdirde elindeki menkul kıymetleri piyasaya göre daha yüksek fiyattan satma hakkı doğacaktır. Ancak fiyatlar alıcının beklediği yönde gelişmezse, yani fiyatlar yükselirse opsiyonu kullanmak alıcı için karlı olmayacaktır. Piyasada daha yüksek fiyata menkul kıymetlerini satabilecekken daha düşük fiyata opsiyon yazıcısına satmak istemeyecek, dolayısıyla opsiyondan doğan hakkını kullanmayacaktır. Bu durumda ödediği prim kadar bir zararı söz konusu olacaktır.

\begin{tabular}{|l|l|}
\hline SATIM OPSIYONU (Put Option) & KARDA (In The Money) \\
\hline Piyasa Fiyat $1+$ Prim $>$ Kullanım Fiyatı & BAŞABAŞ (At The Money) \\
\hline Piyasa Fiyat $1+$ Prim $=$ Kullanım Fiyatı & ZARARDA (Out Of The Money) \\
\hline Piyasa Fiyat 1 Prim $<$ Kullanım Fiyatı & PAR \\
\hline
\end{tabular}

\subsection{Swap İşlemleri}

Swap işlemleri, farklı kuruluşların, farklı finansal piyasalardaki, farklı kredi değerliliklerine bağlı olarak, farklı kredi şartlarıyla karşı karşıya kalmaları ve bu farklılıklardan swap işlemine taraf olanlardan her birinin yararına olacak şekilde sonuç sağlayan işlemlerdir. 
Swap sözleşmeleri bir borçlanma veya yatırım yöntemi olmayıp sadece mevcut borçların veya yatırımların nakit akımlarını değiştirmeye yarayan finansal araçlardır.

Swap; riskleri azaltma, gelirleri arttırma ve fon maliyetlerini düşürme olanağı veren bir yöntemdir. İşletme yöneticileri, yapacakları swap işlemleriyle, ihtiyaçlarına göre, borçlarını yeniden değerlendirmek için bir araç sağlamakta, para cinsinin ve enstrüman tipinin avantaj sağladığı yerlerden borçlanabilmektedir. Böylece, swap aracılığıyla işletme kaynakları daha etkin bir şekilde kullanabilmektedir.

Swap işlemleri; faiz, para, mal, borsa endeksi ve kredi riski esasına dayalı olarak yapılmaktadır. Bunun yanında, belli başlı birkaç swap işleminin özelliklerinin tek bir işlemde birleştirilmesiyle oluşturulan türetilmiş swap çeşitleri de bulunmaktadır.

a. Faiz Swapı: Taraflar arasında belirli bir dönem için, belirli bir anapara tutarına uygulanacak faiz oranlarının değiştirilmesi amacıyla yapılan sözleşmedir. (Shapiro,1999; 557)

b. Para Swapı: İki tarafın, iki ayrı para birimi üzerinden mevcut veya olacağı tahmin edilen borçlarını veya alacaklarını belirlenmiş kurallar çerçevesinde, kararlaştırılan süre sonunda, daha önce anlaşılmış belirli bir kur üzerinden taraflar arasında değiştirilmesini içeren finansal bir işlemdir.

c. Mal Swapı: İki taraf arasında belirli miktar ve kalitedeki bir malın sabit ve değişken fiyatlarını belirli bir zaman süresince değiştirmeye yönelik bir sözleşmedir. (Korkmaz ve Ceylan, 2012; 442)

d. Swap Opsiyonları: Swap ve opsiyonun birleşiminden oluşur ve swaptions olarak da adlandırılır. Bir swap opsiyonu sözleşmesi, belirli koşullar altında, gelecekte bir swap sözleşmesine girme ya da bir swap sözleşmesini sona erdirme hakkı verir.

\section{TÜREV FINANSAL ARAÇLARIN MUHASEBELEŞTİRILMESINE}

\section{ILIŞKİN DÜZENLEMELER}

Türev finansal araçların, doğru ve özüne uygun bir şekilde muhasebe kayıtlarının yapılması, riskin sayısallaştırılarak mali tablolarda yer alması büyük önem arz etmektedir.

\subsection{Türev Finansal Araçların Kayıt Altına Alınması ile İlgili Sorunlar}

Türev finansal araçların muhasebeleştirilmelerinde karşılaşılan ilk sorun bu araçlar ile ilgili işlemlerin muhasebe kayıtlarına nasıl aktarılması gerektiğidir. Bu araçların bir varlık ya da yükümlülük olarak bilançoda yer alıp almayacağı, kaydın ne zaman ve nasıl yapılacağı gibi sorulara aranan yanıtlar, bu araçların muhasebeleştirilmelerine ilişkin yöntemin seçimi hususunda büyük önem arz etmektedir.

Türev finansal araçlara ilişkin diğer bir sorun, bu araçlara ilişkin sözleşmelerin değerlemelerinin ne şekilde yapılacağı hususudur. Değerleme sorunu, iki aşamalı olarak karşımıza çıkmaktadır. Birincisi, türev araçlar muhasebe kayıtlarına alınırken hangi değerin kullanılacağı, ikincisi ise sonraki dönemlerde değerlemenin ne şekilde yapılacağıdır. 
Türev finansal araçların muhasebeleştirilmesindeki sorunlardan biri de bu araçlara ait bilgilerin finansal raporlarda kamuya nasıl açıklanacağına ilişkindir.

\subsection{Uluslararası Muhasebe Standartlarında Yapılan Düzenlemeler}

Finansal araçların raporlanması konusunda, 1988 yılında, Uluslararası Muhasebe Standartları Komitesi (IASC), finansal araçlar üzerinde çalışmaya başlamıştır.

IASC; 1995'de, UMS - 32 Finansal Araçlar: Sunum ve Açıklamalar Standardını yayınlamıştır. UMS 32 Finansal Araçlar: Sunum Standardının amacı; işletmede bulunan finansal araçların, borç veya özkaynak olarak sınıflandırılmasına ve finansal araçların (finansal varlık ve finansal borçların) netleştirilmelerine ilişkin ilkeleri belirlemektir. UMS 32 standardı; finansal tablo kullanıcıları tarafından, finansal enstrümanların, işletmenin finansal durumu, performansı ve nakit akımları üzerindeki etkilerinin daha iyi anlaşılması ve analiz edilebilmesini amaçlamaktadır.

UMS 32, Türev araçları, "Finansal bir aracın taşıdığı risklerin taraflar arasında değişimini sağlayan sözleşmeler" olarak tanımlayarak kapsamına almış ve ayrıntılı açıklamalara ekinde yer vermiştir. UMS 32'nin ekinde, türev finansal araçlara ilişkin olarak şu açıklamalara yer verilmiştir: Finansal araçlar; asıl araçlar (alacaklar, borçlar ve hisse senedine dayalı finansal araçlar gibi) ile türev finansal araçları (opsiyonlar, vadeli işlem sözleşmeleri, futures sözleşmeler ve forward sözleşmeler, swap işlemleri vb.) içerir.

IASC, 1999'da UMS - 39 Finansal Araçlar: Muhasebeleştirme ve Değerleme Standardını yayınlamıştır. UMS 39 standardının amacı; finansal varlıkların, finansal borçların ve finansal olmayan kalemlerin alım veya satımına ilişkin sözleşmelerin muhasebeleştirme ve ölçülmesine yönelik ilkeleri belirlemektir.

UMS 39 nolu standartla getirilen temel ilkelerden biri; türev araçlar dahil tüm varlık ve yükümlülüklerin bilançoya yansıtılmasıdır. UMS 39 kapsamında; finansal varlıklar veya finansal borçlar, sadece işletmenin bir araca ilişkin sözleşme hükümlerine taraf olması halinde, bilançoya yansıtılmak üzere mali tablolara alınmaktadır. $\mathrm{Bu}$ ilke, türev araçlara ilişkin sözleşme ile belirlenen tüm hakların ve sorumlulukların, bilançoda varlıklar ve yükümlülükler olarak mali tablolara alınmasını gerektirir. Bir finansal borç veya bu borcun bir kısmı; sözleşmede belirtilen yükümlülüğün ifası, sona ermesi veya iptal edilmesi gibi nedenlerle, sadece borcun ortadan kalkması halinde mali tablolardan çıkarılır.

Uluslararası Muhasebe Standartları Kurulu (IASB), gerçekleştirdiği gelişme faaliyetleri sonucunda finansal araçların açıklamasını UMS - 32 kapsamından çıkarmış ve UFRS - 7: Açıklamalar standardını, 01.01.2007 tarihinden itibaren yürürlüğe koymuştur. UFRS 7 Finansal Araçlar: Açıklamalar Standardının amacı; finansal tablo kullanıcılarının, finansal araçların işletmenin finansal durumu ve performansı açısından önemi ve işletmenin dönem içerisinde ve raporlama tarihinde finansal araçlar nedeniyle maruz kaldığ 1 risklerin niteliği ve düzeyi ile işletmenin riskleri yönetme şeklini değerlendirebilmeleri için gerekli olan bilgilerin kamuoyuna açıklanmasıdır.

UFRS 7'de yer alan ilkeler, "UMS 32 Finansal Araçlar: Sunum”, "UMS 39 Finansal Araçlar: Muhasebeleştirme ve Ölçme” ve "UFRS 9 Finansal Araçlar” Standartlarında yer alan 
finansal varlık ve borçların muhasebeleştirilmesi, ölçülmesi ve sunumuna ilişkin ilkeleri tamamlar.

Uluslararası Muhasebe Standartları Kurulu, UMS - 39 nolu standardın yerini almak üzere de yeni bir çalışma başlatmış ve bu kapsamda 12.11.2009 tarihinde UFRS 9: Finansal Araçlar Standardının ilk kısmını yayınlamıştır. Standardın ilk kısmında finansal varlıkların sınıflandırılması ve ölçümüne ilişsin ilkeler belirlenmiştir.

IASB'nin böyle bir proje başlatmasının nedeni, yatırımcilar ve diğer finansal tablo kullanıcılarının UMS 39'da yer alan muhasebeleştirme ve ölçümleme esaslarının anlaşılması ve uygulamasının zor olduğunu ifade etmeleridir.

Standardın amacı, finansal tablo kullanıcılarına işletmenin finansal varlıkları ve finansal borçları ile ilgili olarak, gelecekte ortaya çıkacak nakit akışlarının tutarı, zamanlaması ve belirsizliği hakkında, ihtiyaca uygun ve yararlı bilgiyi sunacak raporlama ilkelerini belirlemektir. UMS 39'un kapsamı içinde yer alan tüm finansal araçlara bu standartta yer alan hükümler uygulanır.

IASB tarafindan, UFRS 9'un değer düşüklüğü ve finansal riskten korunma muhasebesi kısımlarının da tamamlanmasıyla birlikte, UFRS 9 bir bütün olarak 2018 yılında yürürlüğe girmiştir.

UFRS 9 Finansal Araçlar Standardının Türkiye'de uygulanacak versiyonu, Kamu Gözetimi Muhasebe ve Denetim Standartları Kurulu (KGK) tarafindan kabul edilmiş ve TFRS 9 Finansal Araçlar (2017 Sürüm) adıyla, 01.01.2018 tarihinde ve sonrasında başlayan hesap dönemleri için uygulanmak üzere 19.01.2017 tarih ve 29953 sayılı Resmî Gazete'de yayımlanmıştır.

\subsection{Türev Finansal Araçların Muhasebeleştirilmesine İlişkin Hususlar}

Türev ürünlere olan ilginin artması, bu ürünlerle ilgili muhasebeleştirme ilkelerine olan ihtiyacı doğurmuştur. Bu ilkeler, ilk defa Uluslararası Finansal Raporlama Standartlarında UFRS/TFRS 9 Finansal Araçlar Standardında detaylı olarak ele alınmıı̧tır. Ancak, TFRS 9'daki ilkeler daha çok sermaye piyasalarına tabi işletmelere yöneliktir. Bu ürünleri kullanmak isteyen daha küçük işletmelere yönelik daha basit muhasebeleştirme ilkeleri geliştirilmiştir. Sermaye piyasası mevzuatına tabi olmayan işletmelerin kullanacakları ilkeler BOBİ FRS olarak yayınlanan ve 01.01 .2018 'den itibaren yürürlüğe giren standartlarda yer almıştır. (Dinç ve Atasel, 2018; 1186)

BOBİ FRS'nin 9.47 nolu paragrafinda, türev finansal araçlarla ilgili olarak, işletme dışından kaynaklanan;

1. Faiz oranı riski,

2. Kur riski,

3. Fiyat riski sözkonusu olduğunda riskten korunma muhasebesi uygulanabileceği belirtilmektedir.

Diğer işlemlerin muhasebeleştirilmesinde olduğu gibi türev ürünlerin muhasebeleştirilmesinde de, muhasebenin temel kavramlarına uygun hareket edilmesi gerekir. 
Bu kavramlardan; tam açıklama, dönemsellik, tutarlılık, özün önceliği ve ihtiyatlılık kavramları, bu konuyla ilgili en önemli kavramlardır. (Parlakkaya, 2005; 172)

Bu kavramlardan tam açıklama kavramı; türev ürünlerin başlangıç kaydında ve mali tablo düzenleme döneminde önem arz etmektedir. Dönemsellik kavramı ise; türev ürünlerle ilgili kar ve zararların dönemlerle ilişkilendirilmesinde dikkate alınacak bir kavramdır. Tutarlılık kavramı; türev ürünlerle ilgili olarak alınan pozisyona ya da kar veya zarar durumuna göre farklı muhasebe politikaları uygulanmayıp, bu konuda tutarlı olunması gereğini ifade eden bir kavramdır. Özün önceliği kavramı; türev ürünlerle ilgili işlemlerin firma için ifade ettiği gerçeğin göz önünde tutulması gereğini belirtir.

Çalışmamızda ana amaç riskin sayısallaştırılması ve mali tablolarda gösterilmesidir. Bu çalışmanın bir diğer amacı ise, Kamu Gözetim Kurulu'nca yayımlanan yeni Hesap Planı Taslağı'ndaki hesap kodlarına ve işleyişine katkı sunmaktır. Bu amaçlar doğrultusunda, aşağıda belirtilen yeni hesap kodlarını kullanarak uygulama örneklerinde belirtildiği şekliyle muhasebe kayıtları yapılabilir.

\section{DÖNEN VARLIKLAR}

\section{Türev Araçlar}

119 Türev Araçlar: Alım - satım veya finansal riskten korunma amacıyla, en fazla oniki ay elde bulundurmak için yapılan türev sözleşmelerin izlendiği hesaptır.

119.01 Alım Amaçlı Forward Sözleşme

119.02 Satım Amaçlı Forward Sözleşmesi

119.03 Alım Amaçlı Futures Sözleşme

119.04 Satım Amaçlı Futures Sözleşmesi

119.05 Opsiyon Primleri

2 DURAN VARLIKLAR

20 Türev Araçlar

209 Türev Araçlar: Alım - satım veya finansal riskten korunma amacıyla, on iki aydan fazla elde bulundurmak için yapılan türev sözleşmelerin izlendiği hesaptır.

209.01 Alım Amaçlı Forward Sözleşme

209.02 Satım Amaçlı Forward Sözleşmesi

209.03 Alım Amaçlı Futures Sözleşme

209.04 Satım Amaçlı Futures Sözleşmesi

219.05 Opsiyon Primleri 


\section{KISA VADELİ YABANCI KAYNAKLAR}

30 Türev Araçlardan Borçlar

309 Türev Araçlardan Borçlar: On iki aydan kısa süreli türev araç işlemlerinden doğan kısa vadeli borçların izlenmesinde kullanılan hesaptır.

309.01 Alım Amaçlı Forward Sözleşmesinden Borçlar

309.02 Satım Amaçl1 Forward Sözleşmesinden Borçlar

309.03 Alım Amaçlı Futures Sözleşmesinden Borçlar

309.04 Satım Amaçlı Futures Sözleşmesinden Borçlar

4 UZUN VADELİ YABANCI KAYNAKLAR

40 Türev Araçlardan Borçlar

409 Türev Araçlardan Borçlar: On iki aydan uzun süreli türev araç işlemlerinden doğan uzun vadeli borçların izlenmesinde kullanılan hesaptır.

409.01 Alım Amaçlı Forward Sözleşmesinden Borçlar

409.02 Satım Amaçlı Forward Sözleşmesinden Borçlar

409.03 Alım Amaçlı Futures Sözleşmesinden Borçlar

409.04 Satım Amaçlı Futures Sözleşmesinden Borçlar

\section{GELİR TABLOSU HESAPLARI}

66 Finansal Gelirler

667 Türev Araçlardan Sağlanan Kazançlar: Türev finansal sözleşmeden sağlanan karların izlenebildiği hesaptır.

67 Finansal Giderler (-)

677 Türev Araçlardan Kaynaklanan Zararlar (-): Türev finansal sözleşmeden doğan zararların izlenebildiği hesaptır. 


\section{TÜREV FINANSAL ARAÇLARIN MUHASEBELEŞTİRILMESINE İLISSKİN UYGULAMA ÖRNEKLERİ}

\subsection{Forward Sözleşmelerin Muhasebeleştirilmesine İlişsin Örnek}

Denizli'de faaliyet gösteren Ela Tekstil Şirketi, döviz kurundaki dalgalanmalardan korunmak için 02.01.201X tarihinde, 02.07.201X vadeli, forward kuru $1 \$=5,60$ TL'den 250.000 \$ alımı için aracı kurum ile döviz forward sözleşmesi yapıyor.

Sözleşmenin yapıldığı tarihe göre, forward sözleşmesine konu olan tutar:

$250.000 \$ \times 5,60 \mathrm{TL} / \$=1.400 .000 \mathrm{TL}$ 'dir.

Teslim tarihi olan 2 Temmuz 201X'de, Dolar kuru 5,75 TL'ye yükselmiştir. Dolayısıyla, Ela Tekstil Şirketi'nin, forward sözleşmesi ile ilgili kurun yükselişi nedeniyle $250.000 \$ x(5,75 \mathrm{TL} / \$-5,60 \mathrm{TL} / \$)=37.500 \mathrm{TL}$ 'lik türev araç karı söz konusudur.

Forward sözleşmesinin özelliği gereği, vade sonunda teslim mutlaka gerçekleşecektir. $\mathrm{Bu}$ teslimlerle birlikte muhasebe kaydı kapanacaktır. Ela Tekstil Şirketi'nin muhasebe departmanınca, döviz forward sözleşmesinin muhasebeleştirilmesi şu şekilde yapılabilir:

1. Forward sözleşmesine ilişkin 2 Ocak 201X tarihli açılış kaydı:

\begin{tabular}{|c|r|r|}
\hline \multicolumn{1}{|c|}{ 02.01.201X } & Borç & Alacak \\
\hline 119 Türev Araçlar & 1.400 .000 & \\
119.01 Alım Amaçlı Forward Sözleşmesi & & \\
309 Türev Araçlardan Borçlar & & 1.400 .000 \\
309.01 Alım Amaçlı Forward Sözleşmesinden B. & \\
\hline
\end{tabular}

2. Forward sözleşmesinden kaynaklanan 250.000 \$'ın şirket hesabına aktarılmasına ve 37.500 TL'lik türev finansal araç karının yansıtılmasına ilişkin 02.07.201X tarihli muhasebe kayd1:

\begin{tabular}{|c|c|c|}
\hline 02.07.201X & Borç & Alacak \\
\hline $\begin{array}{l}102 \text { Bankalar } \\
102.02 \text { \$ Hesab1 } \\
\qquad 119 \text { Türev Araçlar } \\
\text { 119.01 Alım Amaçlı Forward Sözleşmesi } \\
667 \text { Türev Araçlardan Sağlanan Kazançlar }\end{array}$ & 1.437 .500 & $\begin{array}{r}1.400 .000 \\
37.500\end{array}$ \\
\hline
\end{tabular}

3. 02.07.201X tarihi itibariyle, sözleşmeye konu olan 1.400.000 TL'nin ödenmesi ve türev finansal borç hesabının kapanış kaydı:

\begin{tabular}{|c|r|r|}
\hline \multicolumn{1}{|c|}{ 02.07.201X } & Borç & Alacak \\
\hline 309 Türev Araçlardan Borçlar & 1.400 .000 & \\
316.01 Alım Amaçlı Forward Sözleşmesinden B. & & \\
102 Bankalar & 1.400 .000 \\
\hline
\end{tabular}




\subsection{Futures Sözleşmelerin Muhasebeleştirilmesine İliş̧kin Örnek}

Naz Mermer Şirketi, döviz kurlarında oluşabilecek dalgalanmalardan olumsuz etkilenmemek için aracı kurum vasitasıyla 01/03/201X tarihinde, 01/06/201X vadeli, $€$ Döviz Futures Sözleşmesinde long pozisyon almıştır.

$€$ Futures Sözleşme büyüklüğü $100.000 €$ 'dur. $1 €=6,00$ TL'dir.

Başlangıç teminatı $10.000 €$ olup, bu teminatın \% 80'inin altına düşülmeyecektir. Vade sonunda teslimat yapilacaktır.

Sözleşmenin yapıldı̆̆ı tarihe göre, futures sözleşmesine konu olan tutar: $100.000 € \times 6,00 \mathrm{TL} / €=600.000 \mathrm{TL}$ 'dir.

Başlangıç teminatı da; $10.000 € \times$ x $6,00 \mathrm{TL} / €=60.000$ TL'dir

Teslim tarihi olan 01.06.201X'de, Euro kuru 6,25 TL’ye yükselmiştir.

Dolayısıyla, Naz Şirketi'nin, futures sözleşmesi ile ilgili kurun yükselişinden kaynaklanan $100.000 € \times(6,25 \mathrm{TL} / €-6,00 \mathrm{TL} / €)=25.000$ TL'lik türev araç karı söz konusudur.

Naz Mermer Şirketi Muhasebe Departmanınca, futures sözleşmesinin muhasebeleştirilmesi, şu şekilde yapılabilir:

1. Futures sözleşmesine ilişkin 1 Mart 201X tarihli açılış kaydı:

\begin{tabular}{|c|c|c|}
\hline $01.03 .201 X$ & Borç & Alacak \\
\hline 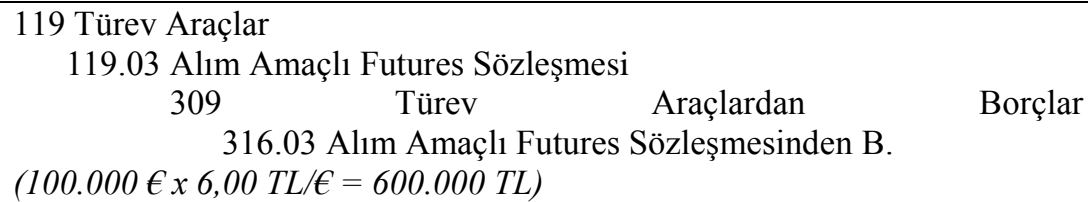 & 600.000 & 600.000 \\
\hline
\end{tabular}

2. Futures sözleşmesi için 1 Mart 201X tarihli başlangıç teminatı kaydı:

\begin{tabular}{|cc|r|r|}
\hline \multicolumn{2}{|c|}{$01.03 .201 \mathrm{X}$} & Borç & Alacak \\
\hline 126 Verilen Depozito ve Teminatlar & 102 Bankalar & 60.000 & 60.000 \\
$(10.000 € \times 6,00 \mathrm{TL} / €=60.000 \mathrm{TL})$ & $102.02 €$ Hesab1 & & \\
\hline
\end{tabular}

3. Vade tarihi olan 01.06.201X'de, futures sözleşmesine konu 100.000 €'nun işletme hesabına geçmesine ve kurun yükselişinden kaynaklanan türev finansal araç karının yansıtılmasına ilişkin muhasebe kaydı:

\begin{tabular}{|c|c|c|}
\hline $01.06 .201 \mathrm{X}$ & Borç & Alacak \\
\hline $\begin{array}{l}102 \text { Bankalar } \\
102.02 € \text { Hesabı } \\
119 \text { Türev Araçlar } \\
119.03 \text { Alım Amaçlı Futures Sözleşmesi } \\
667 \text { Türev Araçlardan Sağlanan Kazançlar }\end{array}$ & 625.000 & $\begin{array}{r}600.000 \\
25.000\end{array}$ \\
\hline
\end{tabular}


4. 1 Haziran 201X tarihi itibariyle türev finansal borç hesabının kapanış kaydı:

\begin{tabular}{|c|r|r|r|}
\hline & $01.06 .201 X$ & Borç & Alacak \\
\hline $309 \quad$ Araçlardan & Borçlar & 600.000 & \\
309.03 Alım Amaçlı Futures Sözleşmesinden B. & & \\
& 102 Bankalar & & \\
& 102.01 TL Hesab1 & & 600.000 \\
\hline
\end{tabular}

5. Futures sözleşmesi için verilen başlangıç teminatının, 1 Haziran 201X tarihinde geri alınmasına ilişkin muhasebe kaydı:

\begin{tabular}{|c|r|r|}
\hline \multicolumn{1}{|c|}{ 05.05.201X } & Borç & Alacak \\
\hline \multicolumn{1}{|c|}{ Bankalar } & 62.500 & \\
102.02€ Hesab1 & & \\
126 Verilen Depozito ve Teminatlar & & 60.000 \\
640 Kambiyo Karlar1 & 2.500 \\
$(10.000 € \times 6,25 \mathrm{TL} / €=62.500 \mathrm{TL})$ & & \\
\hline
\end{tabular}

6. 31.12.201X Tarihi itibariyle futures sözleşmesinden doğan gelirlerin 690 Dönem Karı veya Zararı hesabına aktarılması:

\begin{tabular}{|l|r|r|}
\hline \multicolumn{1}{|c|}{$31.12 .201 \mathrm{X}$} & Borç & Alacak \\
\hline 667 Türev Araçlardan Sağlanan Kazançlar & 25.000 & \\
640 Kambiyo Karları & 2.500 & 27.500 \\
690 Dönem Karı & & \\
\hline
\end{tabular}

\subsection{Opsiyon Sözleşmelerin Muhasebeleştirilmesine İlişsin Örnek:}

Melisa İhracat - İthalat Şirketi, kur değişimlerinden etkilenmemek için Vadeli Opsiyon Borsası'ndan, 01/06/201X tarihinde, 200.000 \$ tutarında, 3 ay vadeli alım opsiyon sözleşmesi imzalamıştır. Opsiyon primi her 1 \$ için 0,025 \$/TL olarak belirlenmiştir.

Sözleşmenin yapıldığı tarihe göre, opsiyon sözleşmesine konu olan tutar:

$200.000 \$$ x 4,60 TL/\$ = 920.000 TL'dir.

Melisa İhracat - İthalat Şirketi, bu opsiyon sözleşmesi için, opsiyon primi olarak;

$200.000 \$ \times 0,025 \mathrm{TL} / \$=5.000 \mathrm{TL}$ ödemiştir.

Vade tarihi olan 01.09.201X'de;

Kullanım fiyatı: $1 \$=4,75$ TL iken Piyasa fiyatı: $1 \$=5,90$ TL olmuştur.

Teslim tarihi olan 01.09.201X'de, Dolar kuru 5,90 TL’ye yükselmiştir. Dolayısıyla, Melisa İhracat - İthalat Şirketi'nin, opsiyon sözleşmesine konu kurun yükselişi nedeniyle 200.000 \$ x $(5,90 \mathrm{TL} / \$-4,75 \mathrm{TL} / \$)=230.000 \mathrm{TL}$ 'lik türev finansal araç kazancı oluşmuştur. Ancak, 
sözleşmenin yapıldığı tarihte $5.000 \mathrm{TL}$ opsiyon primi ödediği için, vade sonunda $230.000 \mathrm{TL}-5.000$ $\mathrm{TL}=225.000$ TL'lik karı söz konusudur.

Melisa İhracat - İthalat Şirketi muhasebe-finans departmanınca, opsiyon sözleşmesinin muhasebeleştirilmesi şu şekilde yapılabilir:

1. Opsiyon sözleşmesine ilişkin 1 Haziran 201X tarihli açılış kaydı:

\begin{tabular}{|c|c|c|}
\hline 01.06.201X & Borç & Alacak \\
\hline $\begin{array}{lc}109 \text { Türev Araçlar } & \\
109.05 \text { Opsiyon Primleri } & 102 \text { Bankalar } \\
& 102.01 \mathrm{TL} \text { Hesab } 1 \\
(200.000 \$ \times 0,025 \mathrm{TL} / \$=5.000 \mathrm{TL}) & \end{array}$ & 5.000 & 5.000 \\
\hline
\end{tabular}

2. Vade tarihi olan 01.09.201X itibariyle, ödenen opsiyon priminin gelir tablosu hesaplarına aktarılmasına ilişkin muhasebe kaydı:

\begin{tabular}{|c|r|r|}
\hline $01.09 .201 X$ & Borç & Alacak \\
\hline $\begin{array}{c}\text { 677 Türev Araçlardan Kaynaklanan Zararlar } \\
\text { 109 Türev Araçlar } \\
116.03 \text { Opsiyon Primleri }\end{array}$ & 5.000 & 5.000 \\
\hline
\end{tabular}

3. 1 Eylül 201X tarihinde, opsiyon sözleşmesine ilişkin 200.000 \$'ın şirkete intikaline ve oluşan türev araç karına ilişkin kayıt:

\begin{tabular}{|c|c|c|}
\hline 01.09.201X & Borç & Alacak \\
\hline $\begin{array}{l}102 \text { Bankalar } \\
102.02 \text { \$ Hesab1 } \\
\qquad \begin{aligned} 102 \text { Bankalar } \\
102.01 \text { TL Hesabı }\end{aligned} \\
667 \text { Türev Araçlardan Sağlanan Kazançlar } \\
{[200.000 \$ \times(5,90 T L / \$-4,75 T L / \$)=230.000 T L]}\end{array}$ & 980.000 & $\begin{array}{l}750.000 \\
230.000\end{array}$ \\
\hline
\end{tabular}

4. Dönem sonu itibariyle oluşan karların ve zararların 690 nolu hesaba aktarılmasına ilişkin muhasebe kaydı:

\begin{tabular}{|lr|r|r|}
\hline \multicolumn{2}{|c|}{$31.12 .201 \mathrm{X}$} & Borç & Alacak \\
\hline 667 Türev Araçlardan Sağlanan Kazançlar & 230.000 & \\
& 690 Dönem Karı & & 230.000 \\
\hline 690 Dönem Zararı & Borç & Alacak \\
& 658 Türev Finansal Araç Zararları & 5.000 & \\
& & 5.000 \\
\hline
\end{tabular}

Türev finansal araçların muhasebeleştirilmesi ile ilgili verilen örnekler, farklı kriterler çerçevesinde çeşitlendirilebilir. Bilindiği gibi, Uluslararası Muhasebe ve Finansal Raporlama Standartları, kural bazlı değil ilke bazlıdır. Dolayısıyla, bu örneklerde kullanılan hesap kodları 
ve muhasebe kayıtları da, Uluslararası Finansal Raporlama Standartları ve muhasebenin temel kavramları dikkate alınarak farklı varyasyonlarda düzenlenebilir.

\section{SONUÇ}

Yirminci yüzyılın sonlarından günümüze kadar gelen süreçte, finansal piyasalarda yaşanan en önemli gelişmelerden biri, piyasalardaki belirsizliklerin ve varlık fiyatlarındaki dalgalanmanın artması sonucunda türev piyasalarda yaşanan hızlı büyümedir. Ayrıca uluslararası ticaretin serbestleşmesi, iletişim teknolojisindeki hızlı gelişme, para ve sermaye piyasalarındaki bütünleşme, vadeli işlem piyasalarında gerek işlem gören sözleşme türü ve sayısını gerekse işlem hacmini önemli ölçüde artırmıştır.

Riskten korunma veya kar elde etme amacıyla etkin bir finansal araç olarak kullanılan türev finansal araçların özüne uygun bir şekilde muhasebeleştirilmesi büyük önem arz etmektedir. Uluslararası boyutta, türev finansal araçların tanımlanması, kayıt altına alınması ve raporlanması konusunu uluslararası finansal raporlama standartları, kapsam altına almıştır. $\mathrm{Bu}$ standartlarla, türev finansal araçların ölçümlenmesi ve muhasebeleştirilmesiyle ilgili global anlamda oluşabilecek sorunların önlenmesi amaçlanmış olup bu hususta çalışmalara devam edilmektedir.

Günümüzde yoğun bir şekilde işlem gören türev finansal araçların kavranması ve muhasebe kayıtlarına alınarak finansal tablolarda şeffaf bir şekilde gösterilmesi amacıyla hazırlanan çalışmada, Türkiye'de kullanılmakta olan Tek Düzen Hesap Planında bazı değişikliklerin yapılması ve yeni hesap kodlarının ilave edilmesi önerilmektedir. Türev finansal araçlara ilişkin işlemlerin, nazım hesaplar kullanılarak kayıtlara alınması yönteminden vazgeçilmesi gerektiği vurgulanmaktadır. Zira, temel amaç riskin gerçek anlamda sayısallaştırılmasıdır.

$\mathrm{Bu}$ çalışmada, uluslararası muhasebe ve finansal raporlama standartları çerçevesinde yapılan kayıtlar, farklı koşul ve stratejilerin uygulanması durumlarında geliştirilmeye açıktır. Bu noktada vurgulanması gereken husus; döviz kurlarındaki, faiz oranlarındaki, fiyatlardaki dalgalanmalardan korunmak amacıyla türev finansal araçları kullanan işletmelere ilişkin finansal tabloların doğru analizi ile bireylerin ve kurumların isabetli karar alma mekanizmalarına sahip olmalarıdır.

\section{KAYNAKLAR}

Akgüç, Öztin (2010), Finansal Yönetim, Avcıol Basın Yayın, İstanbul, 8. Baskı.

Baydoğan, Lütfi (2009), Finansal Araçlar ve Karşılıklar, Türkmen Kitabevi, İstanbul.

Bolak, Mehmet (2004), Risk ve Yönetimi, Birsen Yayınevi, İstanbul.

Canbaş, Serpil - Doğukanlı, Hatice (2012), Finansal Pazarlar, Karahan Kitabevi, Adana, 5. Bask1.

Chambers, Nurgül (2009), Türev Piyasalar, Beta Yayınları, İstanbul, 3. Basım. 
Demir, Volkan (2009), TFRS/UFRS Kapsamında Finansal Araçlar, Nobel Yayın Dağıtım, Ankara.

Dinç, Engin - Atasel, Oğuz Yusuf (2018), "Büyük Ve Orta Boy İşletmeler İçin Finansal Raporlama Standardı (BOBİ FRS) Kapsamında Riskten Korunma Muhasebesi Ve Korunma Yedeği”, Süleyman Demirel Üniversitesi İ.İ.B.F. Dergisi, C:23, S:4, ss.1185-1204.

Karan, Mehmet Baha (2011), Yatırım Analizi ve Portföy Yönetimi, Gazi Kitabevi, Ankara, 3. Bask1.

Korkmaz, Turhan - Ceylan, Ali (2012), Sermaye Piyasası ve Menkul Değer Analizi, Ekin Kitabevi, Bursa, 6. Bask1.

Mısırlıŏglu, İsmail Ufuk (2008), “Türkiye Muhasebe Standartlarına Göre Finansal Araçların Muhasebeleştirilmesi”, Mali Çözüm, İstanbul SMMM Odası Yayını, S: 86, ss. 65-81.

Örten, Remzi - Örten, İpek (2001), Türev Finansal Araçlar ve Muhasebe Uygulamaları, Gazi Kitabevi, Ankara.

Özerhan, Yıldız - Yanık, Serap (2010), IFRS / IAS ile Uyumlu TMS / TFRS, TÜRMOB Yayınlar1 - 377, Ankara.

Parlakkaya, Raif (2005), Finansal Türev Ürünler ile Mali Risk Yönetimi ve Muhasebe Uygulamaları, Nobel Yayın Dağıtım, Ankara.

Seyidoğlu, Halil (2003), Uluslararası Finans, Güzem Can Yayınları, İstanbul, 4. Baskı.

Shapiro, Alan C. (1999), Multinational Financial Management, John Wiley\&Sons Inc., U.S.A., Sixth Edition.

Şavlı, Tuba (2014), Uluslararası / Türkiye Finansal Raporlama Standartları, Yaklaşım Yayınc1lık, Ankara.

T.C. Milli Eğitim Bakanlığı (2007), Türev Piyasa Araçları, Ankara.

T.C. Kamu Gözetimi, Muhasebe ve Denetim Standartları Kurumu (2017), Büyük ve Orta Boy İşletmeler İçin Finansal Raporlama Standardı, Ankara.

T.C. Kamu Gözetimi Muhasebe ve Denetim Standartları Kurumu (KGK), "Finansal Raporlama Standartlarına Uygun Hesap Planı Taslağı", http://www.kgk.gov.tr/Portalv2Uploads/files/Duyurular/v2/TFRS/EK2_Finansal\%20R aporlama\%20Standartlar\%C4\%B1na\%20Uygun\%20Hesap\%20Plan\%C4\%B1\%20Tas la\%C4\%9F\%C4\%B1.pdf, (01.02.2019)

Yalçıner, Kürşat - Tanrıöven, Cihan - Bal, Hasan - Aksoy, Emine Ebru. - Kurt, Çiğdem (2011), Finansal Teknikler ve Türev Araçlar, Detay Yayıncılık, Ankara. 